\title{
Failure to Democratize
}

Exclusive Parliamentary Politics in Nepal (1990-2002)

Sanjeev Humagain and Jungmin Seo

(Yonsei University)

$\langle$ CONTENTS〉

I . Introduction

II . The Issue of Democratization in Nepal

III. Exclusive Parliamentary Politics in Nepal

1. Unprecedented Politicization after 1990: From Panchayat to the NC/UML Era
2. Political History: Continuity and Discontinuity

3. Political Parties

4. Parliament and Cabinet

IV . The Major Consequence: A Nonperforming Democracy

V . Conclusion

- Key words : democratization, exclusive parliamentary politics, nonperforming democracy, Nepal

\section{【ABSTRACT】}

The existing literature on politics in Nepal explores the tragic failure of democratization in the country from three major perspectives: the socalled inherent weakness of Nepalese politics, "exclusionary democratization," and "hybrid regime." In this study, we present an alternative concept, called "exclusive parliamentary politics," for the purpose of performing systematic analysis to explicate Nepal's failed attempt to establish a well-functioning democracy. The concept denotes the continuing domination of a few political elites in parties and 
governments in the democratic era, with no significant changes to political performance and delivery, despite increased political mobilization at the grassroots level, regular general/local elections, and frequent power changes. We find that exclusive parliamentary politics in Nepal, a paradoxical phenomenon, is a comprehensive consequence of certain institutional and historical dimensions, which ultimately led to the failure of democratization.

\section{I . Introduction}

In political and social terms Nepal has travelled a very long way in the past seven decades. Parliamentary democracy was introduced to this small South Asian landlocked country in 1951, with the overthrow of the 104-year-long oligarchic Rana regime. However, in 1960 King Mahendra invoked emergency powers - provided under the 1959 constitution - to dissolve parliament and dismiss the cabinet that had been elected the previous year in the country's historic first democratic election. In addition, he jailed all the cabinet members and a large number of party workers, and banned all political parties. From December 1960 to April 1990, Nepal was ruled by an absolute monarchy under a system of government known as a party-less Panchayat (council) democracy. Multiparty parliamentary democracy was restored through the people's movement (Jana Andolan) in 1990, though external factors also played a significant role. ${ }^{1)}$

The new era of multiparty democracy, however, was marked by instability and strife. The history of the short-lived Nepalese ${ }^{2)}$ democracy, with unprecedented political upheaval, can be divided into two phases. The first is the paradoxical democratic exercise of the 1990s. On the one hand, the

1) For the role of external factors in the democratization of $N$ epal, see Ramjee Parajulee, The Democratic T ransition in N epal (Boston: Rowman \& Littlefield, 2000).

2) Though contested as inaccurate by some, this article uses "N epalese" in the adjective form to refer to something pertaining to $\mathrm{N}$ epal. Some insist on the exclusive use of "N epali." For citations, the original use of the word is left unchanged, thus "N epali" does appear in this article. 
country has successfully conducted three national and two local elections, experimented with all types of governments - majority, minority, and coalitions between the Nepalese Congress (hereinafter "NC"), the National Democratic Party (hereinafter "RPP"), the Nepal Goodwill Party (hereinafter "NSP"), and the Communist Party of Nepal-United Marxist-Leninist (hereinafter "CPN-UML") - regardless of ideological positions and backgrounds. On the other hand, holding elections and experimenting with such coalition exercises has turned out to be less tangible for both institution building and for making agile the spirit of the Constitution. ${ }^{3)}$ Or in Thomas Carothers's words, Nepalese parliamentary democracy became the most representative example of the "feckless pluralism." ") According to Carothers, a country whose political life is marked by feckless pluralism tends to have significant amounts of political freedom, regular elections, and alternation of power between genuinely different political groupings. Despite these positive features, however, democracy remains shallow and troubled. Political participation, though broad at election time, extends little beyond voting. Political elites from all the major parties or groupings are widely perceived as corrupt, self-interested, and ineffective. The alternation of power seems only to trade the country's problems back and forth from one hapless side to the other. Political elites from all the major parties are widely perceived as corrupt, self-interested, dishonest, and not serious about working for their country. The public is seriously disaffected from politics, and while it may still cling to a belief in the ideal of democracy, it is extremely unhappy about the political life of the country. Overall, politics is widely seen as a stale, corrupt, elite-dominated domain that delivers little good to the country and commands equally little respect. Additionally, the state remains persistently weak. Economic policy is often poorly conceived and executed, and economic performance is frequently bad or even calamitous. Social and political reforms are similarly tenuous, and successive governments are unable to make headway on most of the major problems facing the country: from crime and corruption, to health, education, and public welfare more

3) Lok Raj Baral (ed.), Election and Governance in N epal (N ew D elhi: M anohar Publishers \& Distributors, 2005), p. 14.

4) Thomas Carothers, "The End of the Transition Paradigm." Journal of D emocracy 13-1 (2002), pp. 10-11. 
generally. ${ }^{5)}$ The Nepalese democracy has been fraught with all these characteristics.

The second phase, which started in 2001, is mostly the aftermath of the palace massacre. As such, it is labelled as the politics of violence and the rise of two extreme forces: an ideologically-motivated ultra leftist force known as the Nepal Communist Party (NCP [Maoist]), which sought to establish a communist republic through a violent insurgency; and an ambitious ultra rightist force represented by the King, who refused to accept the role of a constitutional monarch and imposed his direct rule by sidelining an elected government. ${ }^{6)}$ A series of incidents haunt the national psyche and have introduced new uncertainties into an already precarious situation. These incidents include: a decade-long Maoist insurgency (1996-2006), which intensified after 2001 and eventually claimed more than thirteen thousand lives and displaced hundreds of thousands of people from their hometowns, the palace massacre in 2001 when King Birendra and his entire immediate family were either killed or fatally injured, the dismissal of parliament and seizure of power by King Gyanendra in October 2002 and again in February 2005, the secularization of the world's only officially Hindu state in 2006, and the abolishment of the 240-year-old monarchy in 2008. Although the Maoist insurgency ended seven years ago, the peace process remains incomplete. ${ }^{7)}$ The major political actors have yet to reach an agreement regarding the Republic of Nepal's new regime model-federalism, presidentialism, or parliamentarism. The Constituent Assembly dissolved in May 2012 without delivering a statute.

This article limits its scope to the first phase of democratic practice. ${ }^{8}{ }^{8}$ It examines why Nepal's attempt to establish a well-functioning parliamentary democracy in the 1990s failed. Though there were very rare positive changes that parliamentary democracy brought in Nepal, this article focuses on the

5) Ibid.

6) Ramjee Parajulee, "An Experiment with a H ybrid Regime in N epal (1990-2006)," Journal of Asian and African Studies 45-1 (2010), pp. 87-88.

7) Andrew H all, "N epal: An Incomplete Peace," Asian Affairs 42-3 (2011), pp. 403-418.

8) Why the royal activism and $M$ aoist insurgency emerged and intensified in $\mathrm{N}$ epal is beyond the scope of this research. The nature of sociopolitical violence and political development in N epal before and after 2001 is entirely different. Since 2001, the political crisis in N epal has been something more than a rollback of democracy. It was the conflict for the whole state restructuring and also the period of brutal civil war. 
ineffectiveness of democratic governments, the poor governance (including the lack of rule of law and rampant corruption, and the emergence/ reinforcement of frustrating political practise, i.e., intensification of inter and intra-party wrangling, buying off lawmakers in order to make or break a government, and the widespread use of "money and muscle" in elections as the major indicators of a nonperforming democracy). Moreover, the gradually increasing public distrust toward the democratic system and political leaders is also considered as an important dimension of Nepal's nonperforming democracy. How the institutional dimensions (regime type), the nature of democratization movement, the power relations before/after the establishment of democracy (political practices), the geopolitical location (open border with India), and the political history (long tradition of self-imposed exile culture) have affected the crisis of democratization are systematically examined.

The reasons behind the tragic failure of democratization in Nepal are examined from three major perspectives: the so-called inherent weakness of Nepalese politics and the two most popular categorizations of Nepalese democracy, which are "exclusionary democratization"9) and "hybrid regime." ${ }^{10)}$ By indicating their limitations, this article presents an alternative concept, called "exclusive parliamentary politics," to explore the tragic failure of democratization in Nepal. Exclusive parliamentary politics is a paradoxical phenomenon that appeared in Nepal during the 1990s: continuous dominance of the few political leaders in both political parties and government, with no significant changes to political performance and delivery ${ }^{11}{ }^{11}$ despite the increase in political mobilization at the grassroots level and regular parliamentary/local elections. The NC and the CPN-UML ${ }^{12}$ claimed to have 1.5 million and four hundred thousand party members, respectively. ${ }^{13)}$ Not only the mother organizations but also their sister

9) M ahendra Lawoti, "Exclusionary Democratization in Nepal 1990-2002," Democratization 15-2 (April 2008), p. 365.

10) Ramjee Parajulee, "An Experiment with a H ybrid Regime in N epal (1990-2006)," Journal of Asian and African Studies 45-1 (2010).

11) Ina Acharya, "W orking Under M onarchy: Political Leadership and D emocracy in N epal," Asian Politics\& Policy 1-1 (January-M arch 2009), p. 127.

12) The NC and CPN-UML were the two major political parties in democratic Nepal. D uring the twelve years of democratic practice, the $\mathrm{N} C$ headed the government for more than ten years. Except for its onetime alliance with the $\mathrm{NC}$ for a coalition government, the CPN -U M L al ways served as the main opposition party. 
organizations mobilized the different population groups. NC has twelve official national level sister organizations and thirteen well-wisher organizations in various sectors. ${ }^{14)} \mathrm{CPN}-\mathrm{UML}$ also has the same number of official sister organizations. Most of them have central and district level organizational structures. The mobilization of students in each mass demonstration and strike were the most remarkable phenomena in democratic Nepal; they could not, however, affect change on the power sharing mechanisms and the decision-making process of political parties.

The political leadership of the major political parties remained steady. Mobilization at the grassroots level could not bring change at the central level. Though one democratic cabinet after another failed to improve the socioeconomic condition of its people and institutionalization of democratic practice, ministers in each cabinet were rarely changed. Out of eighteen fullministers in Sher Bahadur Deuba's cabinet in 2001, only two ministers lacked any ministerial experience from the democratic era. Among the latter, Premlal Singh was the mayor of Kathmandu, the capital city of Nepal, from 1992 to 1997. Though the same person joined the cabinet, his/her portfolios often changed according to his/her personal intimacy with the prime minister.

\section{The Issue of Democratization in Nepal}

The high expectations of the Nepalese following the restoration of democracy quickly turned to dissatisfaction and disillusionment due to dysfunctional democratic governments (acute economic underdevelopment and poverty, incompetent governance, ${ }^{15)}$ and the persistence of discrimination, distrust and conflict among castes and ethnic groups) and frustrating political practices (rampant corruption, intensification of inter and intra-party wrangling, buying off lawmakers in order to make or break a government, frequent changes of government, and widespread use of money and muscle in

13) K. C. Suri, Political Parties in South Asia: The Challenge of Change (Stockholm: IDEA, 2007), p. 71.

14) See "Sister and W ell-wisher O rganizations," N epali Congress website, available at «ttp://www.nepalicongress. org/index.php?linkld=30> (accessed on 23 M ay 2013).

15) See the W orld Bank's Worldwide Governance Indicators, available at বhttp://info.worldbank.org/ governance/wgi/index.asp> (accessed on 1 D ecember 2012). 
elections). In fact, the country's social, economic, and political problems intensified with the restoration of democracy.

Nepal went to the polls in November 1994, just three-and-half years after the first general election under the new multiparty democratic system, indicating a crisis of stability in the country. ${ }^{16)}$ Simmering political tensions between the ruling and opposition parties, and intra-party conflict among the three main leaders of the ruling NC that had bagged a comfortable majority in the 1991 general elections and formed a majority government, signaled the tragic end of the country's first democratically elected parliament. Political instability and uncertainty came to a peak after the 1994 midterm election. ${ }^{17)}$ None of the political parties managed to receive the required number of seats to form a majority government. Between 1995 and 1999, some half-dozen different coalitions came to power, involving some very unlikely bedfellows. ${ }^{18)}$ Ideology has not posed any great obstacle to forging party alliances and seat adjustments. ${ }^{19)}$ The resulting strange combinations were labeled "ill-assorted coalition"20) and "unholy alliance."21) Political instability continued and transformed into a new pattern after the third legislative election in 1999. The NC won a workable majority. Three leaders from the NC formed three different governments in as many years (1999-2002). A coup d'etat by King Gyanendra, who ascended the throne in 2001, removed the NC's third prime minister, Sher Bahadur Deuba, in October 2002. This was the beginning of royal activism in Nepal after the restoration of democracy. Later, the king nominated three prime ministers until the year 2005. The Maoist insurgency which started in 1996 intensified in the rural areas of the country after 2001. Thirteen thousand Nepalese lost their lives

16) Lok Raj Baral, "The 1994 N epal Election: Emerging Trends in Party Politics," Asian Survey 35-5 (M ay 1995), p. 426.

17) Y. K. K hanal, "Nepal in 1997: Political Stability Eludes," Asian Survey 38-2 (February 1998), pp. 148-154.

18) M ichael H utt, "M onarchy, M aoism and D emocracy in N epal," Conflict, Security \& D evelopment 1-2 (2001), p. 95.

19) K. C. Suri, op. cit., p. 65; K rishna H achhethu, "N epal in 1996: Experimenting with a Coalition Government," Asian Survey 37-2 (February 1997), p. 149.

20) "W orld N ews Briefs: After Political Reversal, Premier of N epal Resigns," N ew York Times (5 0 ctober 1997), available at বttp://www.nytimes.com/1997/10/05/world/world-newsbriefs-after-political-reversal-premier-of-nepal-resigns.html> (accessed on $1 \mathrm{D}$ ecember 2012).

21) Krishna H achhethu, op. cit., p. 149. 
during the Maoist insurgency, of which only 608 fatalities had been reported by October 2001.22) The precarious journey to democracy finally ended in 2005 after King Gyanendra seized total power.

The reasons behind this tragic failure of democratization are examined from three major perspectives. First, during the early 1990s, a large number of academic studies have pointed to the inherent weakness of Nepalese politics. As Krishna Bhattachan has put forward, the popular terms of issues taken up by the Nepalese during the early years of democratization were "conspiracy, mockery, nepotism, favoritism, sycophancy, Koiralaization (indicates the family politics in NC party), authoritarianism, commissionocracy, abuse of power and authority, price hikes and pollutions." ${ }^{233}$ Factionalism within the major political parties, conflict inside the $\mathrm{NC}^{24)}$ and frequent changes in government are often presented as the major inherent weaknesses of Nepalese democracy dating from the early years of democratization. Ten governments were formed in just twelve years (1990-2002), and various cabinets were reshuffled more than thirty times in the same period.

Two popular categorizations of Nepalese democracy -"exclusionary democratization" ${ }^{25)}$ and "hybrid regime" ${ }^{26)}$ - are the most representative in academic works that attempt to explore the political crisis in Nepal. ${ }^{27)}$ Both

22) Krishna H achhethu, "The $\mathrm{N}$ epal State and M aoist Insurgency, 1996-2001," in M ichael H utt (ed.), H imalayan People's War: N epal's M aoist Rebellion (Indiana: Indiana U niversity Press, 2004), p. 58.

23) Krishna B. Bhattachan, "N epal in 1993: Business as U sual," Asian Survey 34-2 (February 1994), pp. 175-180.

24) Anirudha Gupta, "N epali Congress and Post-Panchayat Politics," Economics and Political Weekly 29-43 (O ctober 1994), pp. 2798-2801; Girish C. Regmi, "N epal in 1992: Exercising Parliamentary Politics," Asian Survey 33-2 (February 1993); Brad Adams, "N epal at the Precipice," Foreign Affairs 84-5 (September-0 ctober 2005), p. 125; Bhekh B. Thapa, "N epal in 1991: A Consolidation of D emocratic Pluralism," Asian Survey 32-2 (February 1992), pp. 175-181; N arayan Khadka, "D emocracy and D evelopment in N epal: Prospects and Challenges," Pacific Affairs 66-1 (1993), pp. 65-66.

25) Lawoti defines N epalese exclusionary democratization as "the contradictory phenomenon of continuation or increase in the political exclusion [of various caste and ethnic groups] in governance despite universal adult franchise and the increase in political mobilization of marginalized group." M ahendra Lawoti, op. cit., p. 365.

26) Following the framework offered by Diamond, Levitsky and Way, and others, Parajulee defines that N epalese polity introduced in 1990 was in fact a form of "hybrid regime," which contained few democratic provisions but suffered from multiple impediments. Rajmee Parajulee, op. cit., p. 88.

27) For the global trends of categorizing the democratic regime, see Fareed Zakaria, "Illiberal 
appeared in academic debate only since the early years of this new millennium. They view that the emergence of the extreme forces, especially the Maoist insurgency, is a very natural consequence of imperfect and nonperforming democracy. In this sense, both are sequential explanations. The literatures which place emphasis on the ethnic (and gender) dimensions fall into the first category. They relied on the historical and institutional explanations. Historically, often emphasized is the prevalence of a small group of people consisting mainly of Brahman and Chhetri (who make up less than $30 \%$ of the population ${ }^{28)}$ at the top of the country's social, economic, and political sectors since the unification of the Nepalese state. Institutionally, both formal institutions (electoral system ${ }^{29)}$ and unitary governance structure ${ }^{30)}$ and informal institutions (religious traditions, patriarchy, kinship structure, control over resources, and male-dominated political structure ${ }^{31)}$ have choked political participation by most ethnic groups and women. Among these factors, the Hinduization of the state is viewed as the main institutional barrier.

Parajulee presented the five dimensions of hybrid democracy in Nepal: civilian control of the military, politics of marginalization and discrimination, limited civil and political rights, lack of institutionalization, and centralized power structure. Arguments regarding the continuous role played by Narayanhiti (the former royal palace) use, as their starting point, the palace's intervention during the drafting of the constitution. ${ }^{32)}$ In this view, the

Democracy," Foreign Affairs 76-6 (1997), pp. 22-43; Larry Diamond, "Thinking About H ybrid Regimes," Journal of Democracy 13-2 (2002), pp. 21-35; Steven Levitsky and Luncan A. W ay, "The Rise of Competitive Authoritarianism," Journal of D emocracy 13-2 (2002), pp. 51-65; David Collier and Steven Levitsky, "D emocracy with Adjectives: Conceptual Innovation in Comparative Research," W orld Politics 49-3 (1997), pp. 430-451.

28) Ganga B. Thapa and Jan Sharma, "From Insurgency to Democracy: The Challenges of Peace and Democracy-Building in N epal," International Political Science Review 3-2 (2009), p. 208.

29) First-past-the-post (FPTP) system.

30) M ahendra Lawoti, op. cit., pp. 363-385.

31) M ahendra Lawoti, "Informal Institution and Exclusion in Democratic N epal," H imalaya 28-1 \& 2 (April 2008), pp. 12-32.

32) For the constitution drafting process in $\mathrm{N}$ epal, see Krishna $\mathrm{H}$ achhethu, "M ass M ovement 1990," Contributions to N epalese Studies 17-2 (July 1990), pp. 177-201; M ichael H utt, "D rafting the N epal Constitution, 1990," Asian Survey 31-11 (N ovember 1991), pp. 10201039; Ram K. G himere, "2046 salko jana andal oka ghatanhauharuko binran: ek addhyan" [A Study on the M ass M ovement 1990], Contributions to N epalese Studies 19-2 (July 1992), pp. 283-307. 
restoration of democracy in 1990 did not completely resolve the issue of power and the role of the monarchy in a multiparty democratic system. ${ }^{33)}$ The Holeri incident of 2001 - wherein the army disobeyed the parliamentary government's decision to counter the Maoist guerrillas after they took seventy-six police officers hostage on 12 July 2001 at Holeri in Rolpa district - is the most cited example used to explore both the continuous role of the king in running the state and the lack of civilian control over the military in democratic Nepal.

Though the literature on the so-called inherent weakness of Nepalese politics correctly indicates the problems of Nepalese democracy, it makes fewer efforts to explore its causal mechanism. The chronological explanations have mostly focused on the political dynamics after democratization. Systematic analysis of how institutional dimensions, the nature of democratization movement, the power relations before the establishment of democracy, and the geopolitical situation of the country have affected the crisis of democratization has been rare. On the other hand, two popular categorizations allude to the nonperforming and instable democracy as a natural and given phenomena. The excessive focus on the sequential explanations - how their categories were associated with the rise and intensification of Maoist insurgency and royal activism - hindered discussion on the failure mechanism of a democratic system. In the next section, we present a new concept called "exclusive parliamentary politics" as a way to explore how Nepal's attempt to establish a well-performing parliamentary democracy failed.

\section{Exclusive Parliamentary Politics in Nepal}

The scope of "exclusive parliamentary politics" varies considerably from the popular terms "exclusionary democratization" and "hybrid regime." In particular, exclusionary democratization emphasizes the dominance of the caste hill Hindu elite (hereinafter $\mathrm{CHHE}^{34)}$ at the top of the country's social,

33) Padmaka M urthy, "Understanding N epal M aoist's D emand: Revisiting Events of 1990," Strategic Analysis 27-1 (January-M arch 2003), pp. 12-13.

34) $M$ ahendra Lawoti, op. cit., p. 366. 
economic, and political sectors. It has two major limitations when it comes to explaining the tragic failure of democratization in Nepal. First, ethnic exclusion was not the core element of the exclusionary politics in Nepal. ${ }^{35}$ In democratic Nepal, political identity - one's belonging to the political parties, especially NC and CPN-UML - was the most important identity for political and socioeconomic opportunities. Though Bal Bahadur Rai was non-CHHE, he was able to become the acting Prime Minister of Nepal nineteen times. His political identity, a senior member of NC, and his personal intimacy with the prime minister, played a salient role in his ability to stay in the center of power. Winning elections was not an exception. Ethnic and caste identity rarely affected the result of the election. ${ }^{36)}$ Second, not all the CHHE members received equal socioeconomic and political opportunities. For instance, the far-west regions were and still remain the most underdeveloped provinces in Nepal, where the Chhetris constitute the majority of the population. Moreover, the dichotomous classification between ruling and ruled ethnic groups is not an appropriate explanation for the role of the caste system and ethnicity in politics. Not only the inter-caste system but also the intra-caste system among the different group ${ }^{37)}$ should be considered carefully in the interpretation of hierarchical relations among caste and ethnic groups in Nepal. Hence the need to reexamine politically excluded groups and how such exclusion was made possible. The hybrid regime, on the other hand, underlines Nepal's difficulties with democratization arising from the lack of institutionalization. However, it fails to explain two important questions about Nepalese democracy: 1) why regular elections and power transition were not associated with the institutionalization of parliamentary democracy; and 2) why democratic governments failed to institutionalize democratic practices.

In an attempt to address these shortcomings, we present the alternative concept of "exclusive parliamentary politics." Though it does not completely

35) M ost literature often failed to differentiate between social and political exclusion in $\mathrm{N}$ epal. They used social and political exclusion as synonyms. Whether one's social identity is as equally important in $\mathrm{N}$ epalese politics is still a matter for examination.

36) Fred Gaige and John Scholz, "The 1991 Parliamentary Elections in N epal: Political Freedom and Stability," Asian Survey 31-11 (N ovember 1991), pp. 1040-1060.

37) See John Whelpton, A H istory of N epal (Cambridge: Cambridge U niversity Press, 2005), pp. 9-10. 
fill the void in the literature, it explicates why the political elites, though numerically small, were able to continuously remain in power despite the fact that they were unable to improve social or economic conditions for the people. Furthermore, despite an the increase in mobilization, regular elections, and political parties conventions in Nepal, this concept addresses why no changes were made to the political structure and what determined inclusion/exclusion and how exclusion/inclusion shaped the future of the country's democratization.

Exclusive parliamentary politics in Nepal was a consequence of political practice and various institutional and historical factors. NC and CPN-UML emerged as the hegemonic actors in democratic Nepal since no third power appeared to balance them. The emergence of the NC/UML era was not natural, however. The nature of the democratization process and the characteristics of the former authoritarian regime, the Panchayat, have contributed to this outcome. The NC and CPN-UML were both institutionally exclusive political parties. In practice, both were controlled by the first generation's leaders. They run their parties mostly based on personal networking. The lack of legal provisions regulating the selection of persons to be put forwarded as candidates in general elections allowed these leaders to maintain their hegemony in the party. The cabinet formation process, on the other hand, was also extremely exclusive. Only cabinet members were allowed to be ministers in Nepal. In sum, exclusive parliamentary democracy was a product of the power distribution after democratization, which channeled power exclusively to political parties. The exclusive political practices, a historical product, contributed to the existence of this kind of exclusive politics in the democratic era.

\section{Unprecedented Politicization after 1990: From Panchayat to the NC/UML Era}

The politicization —or "particization" to be more precise —of all aspects of civilian life was the first and most important change in Nepal after the restoration of democracy. Where the king's position had been weakened considerably and civil society had not developed to such an extent that it was able to check the power of political parties and the government, political parties in democratic Nepal exercised near total range of control. ${ }^{38)}$ There was 
no confusion regarding Robert Dahl's old and prominent question, "who governs"? ${ }^{39)}$ In democratic Nepal, only the elected political elites - the NC and the CPN-UML party, which in practice obtained $87 \%$ of the seats in the 1991 parliamentary election - had control over the governing mechanisms.

However, the hegemonic presence of the NC and the CPN-UML in the new era was not the natural outcome of democratization. The characteristics of Nepal's democratization movement and the lack of a strong third party, which is also explicitly related to the nature of the Panchayat system, comprehensively shaped this consequence. Democracy in Nepal was restored through the mutual agreement between democratization forces - NC and United Left Front (hereinafter "ULF"), which later converted to CPNULM - and the king. Both the various communist groups and former Panchas (who were involved in the Panchayat system) were excluded in the negotiation process. As seen in the first interim government, power in the new democratic Nepal was also explicitly distributed to these three groups only. The new Council of Ministers was made up of eleven ministers: four members of the Congress, three of the ULF, two independents with records of work in human rights organizations, and two palace nominees. ${ }^{40)}$ Power was transferred from Pancha to NC/UML, which could not be challenged by any forces in the first election; this established them as the main actors in the country. Unlike many of its South Asian neighbors, ${ }^{41}$ the authoritarian blocks in Nepal did not have a strong political party. One's individual intimacy with the palace was a more salient characteristic of those who were appointed to major positions in Panchayat era, including the prime minister. Also, after the restoration of democracy, the former Panchas could not unify into a single party. Two former prime ministers of the Panchayat regime contested in the election with two parties: RPP (Chanda) and RPP (Thapa). Frequent splitting among communists in Nepal, ${ }^{42}$ another potential balancer, made the ascent of

38) Gambhir Bhatta, "End of the H oneymoon? Reexamining Democratization and Political Reforms in N epal," Asian Journal of Political Science 7-1 (J une 1999), p. 84.

39) Robert Dahl, Who Governs. D emocracy and Power in an American City (N ew Haven, CT: YaleU niversity Press, 1963).

40) M ichael Hutt, op. cit., p. 1023.

41) Bangladesh presents a contrasting picture, where each authoritarian regime formed its own political party and ruled the country through the party.

42) N arayan K hadka, "Factionalism in the Communist M ovement in N epal," Pacific Affairs 68-1 (Spring 1995), pp. 55-76. 
the NC and CPN-UML much easier.

The emergence of the two-party domination system was not the problem for a well-performing democracy in Nepal. In addition to their exclusive party structure and system, "particization" of every aspect of social, economic, and political life was another problem - the real problem. Only rarely were unpoliticized social and economic sectors in Nepal found. Among them, the particization of the bureaucracy was the most important point to be observed. The 1990 Nepalese constitution does not allow a civil servant to join a political party. In practice, however, most civil servants are affiliated with some sort of civil service employees' association, which are unauthorized. Seven major organizations of civil servants exist. All of them openly accept their affiliation with the mother party. ${ }^{43)}$ On its official website, NC lists the Nepal Civil Service Employees' Union as a well-wisher organization of the party. ${ }^{44)}$ Political leaders from the major parties are often the chief guests at major functions of these organizations. ${ }^{45)}$ In some cases, internal conflict among the main political leaders in the mother party resulted in the split of the civil servants' organization. But the most interesting part of this story is the number of members. The CPN-UML, NC, and Maoist organizations claim to have forty-one thousand, twenty-five thousand, and twenty-two thousand members, respectively. If we add all the numbers claimed by each organization, it exceeds the number of present civil servants in Nepal. ${ }^{46}$

\section{Political History: Continuity and Discontinuity}

In this new era of NC and UML supremacy, who really governed? Most leaders in major positions in political parties and the government after 1990 were from Nepal's first generation of politicians. Three of the main leaders of the NC in 1990 - popularly known as "troika" (K. P. Bhattrai, the acting president and prime minister of the interim government in 1990; Ganeshman Singh, the supreme leader of democratization movement; and G. P. Koirala, the general secretary of the party) - had been active in the party/national

\footnotetext{
43) I bid.

44) See বhttp://www.nepalicongress.org/index.php?linkld=87> (accessed on $23 \mathrm{M}$ ay 2013).

45) See «ttp://karobardaily.com/news > (accessed on 23 M ay 2013).

46) Yoshoda Timalsina, "Politics in Civil Service," N epal N ational Weekly (June 2013), availableat «ttp://www.ekantipur.com/nepal/article/?d=2607> (accessed on 1 D ecember 2012).
} 
politics dating back to before 1950. As supreme leaders, a large majority of the central leaders of the NC (generally the political colleagues of the troika) came from the first-generation leadership of the party. Most of them entered into politics during the anti-Rana movement and in the early phases of the anti-Panchayat movement. This situation was similar to that found in the CPN-UML as well. The UML's chief, Man Mohan Adhakari, was a political colleague of the troika. In fact, the UML consisted of a group of communist leaders who actively participated in the democratization movement, calling themselves the United Left Front.

The persistence of these leaders in major positions resulted from the political culture of (self-imposed) exile in India (India shares an open border with Nepal). The emergence of political parties in Nepal is closely related to the independence movement in India. A few Nepalese youths, most of them either students or relatives of self-imposed political elites, actively participated in the Indian independence movement. Their political interests and associations were expanded to encompass the anti-Rana movement in Nepal. The NC and other communist parties were formed during the same period in India. These Banaras- and Calcutta-based Nepalese politicians came to power in Nepal with the end of the Rana regime. When King Mahendra took power, politicians from the first generation were either jailed or chose self-imposed exile in India. Those who were released from jail chose either to engage in underground politics or to undergo self-imposed exile in India. The practical power in each major party, the $\mathrm{NC}$ and the communist camp, persisted in the hands of just a few leaders for more than half a century.

\section{Political Parties}

How could these old leaders maintain their power in the party and government after the restoration of parliamentary democracy? With regard to the $\mathrm{NC}$, both the central executive body and the decision-making process were exclusive. According to its constitution, ${ }^{47)}$ in order to be the central

47) “N epali Congress Bidhan 2017, 2051, 2054, 2057, 2064, 2066 Amendment," N epali Congress, available at <http://www. nepalicongress.org/files/listingfiles/ $\mathrm{N}$ epali \% 20C ongress $\% 20$ Bidhan $\% 202017 \% 20 \_2051, \% 202054, \% 202057, \% 202062$, $\%$ 202064,\%202066\%20Amendment_.pdf> (accessed on 1 D ecember 2012); regarding the criteria of the central executive committee, see chapter five of the constitution. 
president of the $\mathrm{NC}$, a member had to first put in at least fifteen years as a regular active member of the party. Likewise, in order to join the executive center of the NC, members must first spend a minimum of ten years as a regular active member of the party. Those members belonging to a special quota group (i.e., women, members of a lower caste, indigenous persons, or Muslims) who want to be a central executive member were required to be a regular active member of the party for more than ten years. Moreover, the president of the NC had the authority to nominate $20 \%$ of the central committee members, the chiefs of all central departments, and zone coordinators. Clearly, the president of the NC had considerable authority in the 1990s.

Family politics is another aspect of the NC that rendered it a more exclusive party. The Koirala family, one of the prominent founders of the NC, became an icon in Nepalese society and politics. Since its establishment in 1950, only two presidents of the $\mathrm{NC}$ have been nominated from outside the Koirala family. The patrimonial system within the NC was reinforced in 1991, when Grija Prasad Koirala became the first democratically elected prime minister following the restoration of democracy. Koirala was elected as party president in 1996 by the Ninth National Convention held in Kathmandu. He acted as general secretary of the NC from 1975 to 1991 . His excessive privileging of family members - including his daughter - in the party and the government became the central reason behind intra-party conflict. The incumbent president of the NC, another Koirala family member, was nominated by Girija Prasad Koirala for party chairman. He was nominated as the general secretary of the party in 1996 and then as acting chairman in 2008 by Giraja Prasad Koirala. In the NC, not only members of the Koirala family, but also a large number of family members of other influential leaders were either nominated or elected to major posts within the party and the government. The decision-making system of the NC was and continues to be entirely presidentcentric. Only the president and a few of the party's closest members generally members hailing from the Koirala family - make any major decisions.

Exclusivity in the CPN-UML was a dominant feature of the party; however, this exclusivity differed from that found in the NC. The CPN-UML practiced indirect democracy within the party. The central committee, elected through a general convention, nominated the chief leader of the party. In practice, this 
served to establish the dominance of a few leaders in the party. Madhav Kumar Nepal led the CPN-UML continuously for fifteen years (1993-2008). The general members of the central executive committee had a limited role in the selection of the party chief and the central decision-making process. All major positions in the central committee were elected directly through the general convention for the first time in the party's history in 2009. The political leadership of other smaller major parties also remained steady. Surya Bahadur Thapa was the president of the RPP, the third largest party in parliament from 1990 to 2002. Narayan Man Bijukehhe has led the Nepal Workers and Peasants Party, a small communist party, as president for the past thirty-seven years. Similarly, the Maoist leadership has not changed in twenty years.

\section{Parliament and Cabinet}

In addition to the exclusive structure of political parties, the exclusive nature of the candidate nomination/cabinet formation process formed another pillar of Nepal's exclusive parliamentary politics. There were no legal provisions regulating the selection of persons to be put forward as candidates in general elections. In fact, the nomination process was called "ticket bitearan"-literally, "the distribution of nomination tickets"-rather than the candidate nomination process. Party leadership would decide how to select candidates and who should be selected. Neither the state nor the Election Commission could interfere in the process. ${ }^{48)}$ Grassroots members of political parties rarely participated in the selection process of candidates. ${ }^{49)}$ In democratic Nepal, most candidates in parliamentary elections were chosen by top leaders based on personal loyalty. ${ }^{50)}$ This system also strengthened the personal dominance of the party chief in each party.

The exclusive cabinet formation process strengthened the exclusiveness of parliamentary democracy. Only parliamentarians were allowed to be ministers in democratic Nepal (1990-2005). Nonparliamentarians were

48) K. C. Suri, op. cit., p. 82.

49) Surya P. Subedi, "The Journey from an O ligarchy to a Parliamentary D emocracy: A Case Study of Parliament of N epal," Journal of Legislative Studies 4-4 (1998), p. 180.

50) Gambhir Bhatta, op. cit., p. 84. 
required to become members of parliament within six months from the date of his/her appointment. ${ }^{51)}$ This is a common system in parliamentary democracies, including in the post-British colonial states. However, this system became the single most important tool of exclusive parliamentary democracy in Nepal when it met the exclusive party structure and candidate nomination process of the country's parliamentary elections. Moreover, political parties strictly controlled parliamentarians. A separate parliamentary party could only be formed if $40 \%$ of parliamentarians collectively agreed to disassociate themselves from the parent party.

\section{The Major Consequence: A Nonperforming Democracy}

There were few positive changes that parliamentary democracy brought to Nepal. The state was almost dysfunctional. Though elections are the first basic indicator of democracy, elections have been one of the main problems of democratic process in Nepal. Here we examine how exclusive parliamentary politics in Nepal is associated with its nonperforming democracy.

Ineffectiveness of democratic government is the core part of Nepal's nonperforming democracy. Ineffectiveness was the comprehensive consequence of frail cabinets and a highly politicized and ineffective bureaucracy. As a natural consequence of the political history of the political parties, specifically their structure and exclusive candidate nomination process, only those political elites with a long and intimate personal network with the supreme leaders of the political parties became official candidates in parliamentary elections.

The upper and lower houses in Nepal inevitably became a club for old politicians who only rarely had any special knowledge regarding the running of the state. In the first democratically elected parliament after the restoration of multiparty democracy in 1991, only $20 \%$ of elected legislators had had a profession prior to entering politics. Most of the experienced members were in the upper house, which only rarely produced a cabinet minister. Fifty-five percent of parliamentarians were students before entering politics. This ratio

51) Constitution of $\mathrm{N}$ epal, 1991, Article 38. 
was higher in the lower house where about $40 \%$ of parliamentarians did not even have a bachelor's degree. ${ }^{52)}$ This phenomenon persisted or was informally institutionalized after the 1994 mid-term election. The leadership, structure, and nomination systems of the major parties changed very rarely. The characteristics of the legislative elites elected to the second parliament were exceedingly similar to those of the preceding parliament. Most of the parliamentarians in the lower house had no profession prior to entering politics (a full 53\% were students). Twelve percent of parliamentarians were farmers, and $28 \%$ had worked for an NGO. About $30 \%$ of the parliamentarians in the lower house had no bachelor's degree. ${ }^{53)}$

Constitutionally, the prime minister was only allowed to select ministers from among the parliamentarians mentioned above. In addition to these institutional barriers, the excessive priority placed on kinship and heredity in major political appointments by the Nepalese prime minister was another prominent and integral factor of the nonperforming cabinet. Moreover, prime ministers in Nepal rarely considered the specialization of individual members of parliament in appointing him/her to the position of minister. For example, Govinda Raj Joshi, one of the longest serving ministers in democratic Nepal and a former school teacher, was appointed as minister to the following six different ministries in ten years: Ministry for Education, Culture and Social Welfare (1991-1994), Ministry of Education (1995-1996), Home Ministry (1998), Ministry for Water Resources (1999), Ministry for Local Development, and later the Ministry for Culture, Tourism, and Civil Aviation (2001).

A common characteristic of all democratic cabinets in Nepal was a revolving party leadership - a natural consequence of exclusive parliamentary politics - with no significant change to political performance and delivery. ${ }^{54)}$ Out of eighteen ministers in Sher Bahadur Deuba's cabinet in 2001, only two ministers lacked any ministerial experience from the democratic era. Among the latter, Premlal Singh was the mayor of Kathmandu from 1992 to 1997. Most ministers had been regular guests in the cabinet when the NC was in power. Deuba himself was the Home Minister in the first elected cabinet in

52) Ibid., p. 34.

53) Ibid., p. 49.

54) Ina Acharya, "W orking Under M onarchy: Political Leadership and D emocracy in N epal," Asian Politics\& Policy 1-1 (January-M arch 2009), p. 127. 
1991. He also had a previous eighteen months of prime ministerial experience (September 1995-March 1997). He appointed his 1991 cabinet colleague as Minister of Agriculture and Cooperative. The Finance Minister was reappointed to the same position three times. The Minister of Home and Local Development and the Minister for Water Resources were members of every cabinet formed or joined by the NC, with the exception of one time in 1997 and one time in 2000.

We can trace the initial point of ineffective democratic government back to the relationship between these frail cabinets and the bureaucracy. On the one hand, the elected politicians who rarely had any professional knowledge of the field they were appointed to oversee as minister, regarding matters of statecraft, had no option but to align themselves with the bureaucracy. Ironically, the post-colonial phenomenon found mostly in post-British colonial states ${ }^{55)}$ of an "over-developed bureaucracy" ${ }^{\text {"56) }}$ and "underdeveloped politics" emerged in democratic Nepal — which was never colonized-at the end of the twentieth century. Though the bureaucracy was comparatively overdeveloped, it was highly ineffective because of its own inherent culture, values, and norms..$^{57}$

On the other hand, the bureaucrats were also reliant upon politicians for promotions and professional appointments. As in other fields, the politicization of the bureaucracy rapidly intensified following the restoration of democracy. ${ }^{58)}$ The cabinet and ministers had full authority over the promotion (of high-level officials) and posting of bureaucrats. The chances of being appointed Secretary, or other similarly placed position (such as departmental head or chief of a public enterprise), became a zero-sum game

55) M. Shamsul H aque, "Incongruity Between Bureaucracy and Society in Developing N ations: A Critique," Peace \& Change 22-4 (0 ctober 1997), pp. 432-462.

56) An overdeveloped bureaucracy was a comparative phenomenon (to underdeveloped politics) in N epal. N epalese bureaucracy was not a W eberian type ideal bureaucracy (N arayan Khadka, "D emocracy and D evelopment in N epal: Prospects and Challenges," Pacific Affairs66-1 [1993], p. 62).

57) Rameshwor Dangal, Administrative Culture in N epal: D oes It Reflect the Dominant SocioCulture Values of N epal? (M aster's T hesis, U niversity of Bergen, 2005), pp. 101-102.

58) Arjun Mani Dikshit, "Administrative Challenges and Public Service Commission," in Public Service Commission (ed.), I ssues in Public Service Commission (Kathmandu: PSC, 2007), pp. 114-144; M adhu N. Tiwari, "Governance Reform in Political Transition: The Case of N epal's Civil Service," N epalese J ournal of Public Policy and Governance 24-1 (July 2009), pp. 20-21. 
for those who did not enjoy any personal connections with one or another political party. ${ }^{59)}$ The partisan identity of a given bureaucrat affected his/her appointment and dispatch at the local level, too. Even the posting of primary school teachers had a political agenda in democratic Nepal. The police force was no exception; a series of sackings and reinstatements of police chiefs in 1997 by Home Ministers stand as a remarkable example of the politicization of the police force.

Despite these conditional dependencies, the relationship between the bureaucracy and political circles was far from congenial and did not develop into a partnership or relationship of trust. ${ }^{60)}$ Two-thirds of bureaucrats stated that they - not the politicians - run the country, and that Nepalese politicians serve mainly their own personal and narrow partisan interests rather than the welfare of citizens. ${ }^{61)}$ Cooperation between elected politicians and bureaucrats was only possible when each shared the same partisan identity. Intra-party conflicts and personal line (faction) in political parties gravely affected the loyalty of bureaucrats to the elected political elites. Bureaucrats in Nepal held the view that it is necessary for them to possess political sensitivity and share the political views of their superiors. More than three-quarters of the bureaucrats stated that Nepalese civil servants are not neutral and have political affiliations, ${ }^{62)}$ a fact which has contributed to the division among bureaucrats.

Along with the ineffectiveness of governments, frustrating political practices emerged or were reinforced in the democratic era. Elections became extremely expensive in democratic Nepal. ${ }^{63)}$ Both the exclusive candidate nomination process and the cabinet formation process accelerated the use of money in elections. The processes of nomination were undemocratic. In all parties, candidates running in parliamentary elections were chosen by the party's top leaders based on personal loyalty ${ }^{64)}$ Money also became one of the

59) Rabindra Shakya, "Public Service Commission in the Interim Constitution, 2007 and Its Future Agenda," in Public Service Commission (ed.), I ssues in Public Service Commission (Kathmandu: PSC, 2007), pp. 45-71.

60) Ishtiaq Jamil and Rameshwor D angal, "The State of Bureaucratic Representativeness and Administrative Culture in N epal," Contemporary South Asia 17-2 (June 2009), p. 206.

61) Ibid., p. 205.

62) Ibid.

63) Lok Raj Baral, op. cit.

64) Gambhir Bhatta, op. cit., p. 84. 
major sources for nomination tickets. The money spent to win an election became crucial in democratic Nepal. Ideology and ethnic identity had little impact on Nepalese elections. In most constituencies, the personal strategy of a candidate determined whether the candidate was going to win the election or not. Most elected legislative elites in Nepal came from middle and lower class backgrounds. ${ }^{65)}$ As mentioned earlier, these legislators often had no profession prior to entering politics; agriculture was the main source of their income. ${ }^{66)}$ Nepalese political elites have approached politics as a profession and a source of earnings. ${ }^{67}$ The overriding concern of elected officials who came to power through lavish campaigns was to recoup their expenses. Hence, political corruption was inevitable in democratic Nepal due to the exclusive nature of parliamentary politics. Rather than solving the massive socioeconomic and political problems of the nation, the leadership itself became a major problem.

Along with money, power (the use of physical force) also became widespread in Nepalese elections. ${ }^{68)}$ Since politicians who failed to be elected would be totally excluded from power, individual candidates used all means at their disposal to be elected. "Booth capturing," wherein party loyalists gain control over a polling booth in order to ensure that only their votes are cast or to force voters to cast their ballots openly, became a common feature of elections in several constituencies in Nepal. Several people died and hundreds were injured during election campaigns. ${ }^{69)}$ The ruling parties misused the police and other government forces during election campaigns. Conflicts among political parties during election campaigns continued past the election as well. Often the opposition marched in the streets claiming that the elections had been unfair. Injuries and lose of life in antigovernment demonstrations persisted in democratic Nepal, in addition to the other problems ${ }^{70)}$ In part due

65) Suresh C. Chalise, Sociology of the Legislative Elite in a Developing Society (Kathmandu: Nepal Foundation for Advanced Studies, 1995); Thomas M eyer and Suresh C. Chalise, "Legislative Elites and the N epalese Parliament: A Study of their Class Characteristics," Contributions to N epalese Studies 26-1 (January 1999), pp. 27-64.

66) Ibid.

67) Lok Raj Baral et al., Leadership in N epal (D elhi: Adroit Publisher, 2001), p. 67.

68) I bid.; Lok Raj Baral (ed.), op. cit.

69) Fred G aige and J ohn Scholz, op. cit., p. 1056; Lok Raj Baral, op. cit. p. 435.

70) Girish C. Regmi, "N epal in 1992: Exercising Parliamentary Politics," Asian Survey 33-2 (February 1993), p. 146. 
to its exclusive character, democracy always accompanied violence in Nepal.

\section{Conclusion}

This study examined why Nepal's attempt to establish a well-functioning parliamentary democracy in 1990s failed, and presented the concept "exclusive parliamentary politics" to systematically explain this failure. Exclusive parliamentary politics is a paradoxical phenomenon that appeared in Nepal starting in the 1990s, a phenomenon characterized by the continuous dominance of a few political leaders in both political parties and government with no significant change to political performance and delivery, despite the increase in political mobilization at the grassroots level and regular parliamentary/local elections. This phenomenon ultimately led to the failure of democratization in Nepal.

Despite twenty years of revolutionary political changes, parliamentary democracy in the country remains dysfunctional. Mobilization at the grassroots level could not bring about change at the central level. Ironically, democratization led to the informal institutionalization of a more nondemocratic culture.

\section{REFERENCES}

Acharya, Ina. "Working Under Monarchy: Political Leadership and Democracy in Nepal." Asian Politics \& Policy 1-1. January-March 2009, pp. 127-141.

Adams, Brad. "Nepal at the Precipice." Foreign Affairs 84-5. SeptemberOctober 2005, pp. 121-134.

Adhakary, Dhurba. "Nepal's Army Marching to Political Beat." Asia Times Online. 8 May 2004. Available at <http://www.atimes.com/atimes/ South_Asia/FE08Df03.html> (Accessed on 1 December 2012).

Baral, Lok Raj. "The 1994 Nepal Election: Emerging Trends in Party Politics.” Asian Survey 35-5. May 1995, pp. 426-440.

. Election and Governance in Nepal. Delhi: Manohar Books, 2005.

Baral, Lok Raj, Krishna Hachhethu, Hari Sharma. Leadership in Nepal. Delhi: Adroit Publisher, 2001. 
Bhatta, Gambhir. "End of the Honeymoon? Re-examining Democratization and Political Reforms in Nepal." Asian Journal of Political Science 71. June 1999, pp. 77-107.

Bhattachan, Krishna B. "Nepal in 1993: Business as Usual." Asian Survey 342. February 1994, pp. 175-180.

Bhattrai, Hari P. "Cultural Diversity and Pluralism in Nepal: Emerging Issues and the Search for a New Paradigm." Contributions to Nepalese Studies 31-2. July 2004, pp. 293-340.

Carothers, Thomas. "The End of the Transition Paradigm." Journal of Democracy 13-1. January 2002, pp. 5-21.

Chalise, Suresh C. Sociology of the Legislative Elite in a Developing Society. Kathmandu: Nepal Foundation for Advanced Studies, 1995.

Collier, David and Steven Levitsky. "Democracy with Adjectives: Conceptual Innovation in Comparative Research." World Politics 49-3. April 1997, pp. 430-451.

Dahl, Robert. Who Governs: Democracy and Power in an American City. New Haven, Connecticut: Yale University Press, 1963.

Dangal, Rameshwor. "Administrative Culture in Nepal: Does It Reflect the Dominant Socio-Culture Values of Nepal?" Master's Thesis. University of Bergen, 2005.

deSouza, Peter R., Suhas Palshikar, Yogendra Yadav. "The Democracy Barometers (Part II): Surveying South Asia.” Journal of Democracy 19-1. January 2008, pp. 84-96.

Diamond, Larry. "Elections without Democracy: Thinking About Hybrid Regimes." Journal of Democracy 13-2. April 2002, pp. 21-35.

Dikshit, Arjun Mani. "Administrative Challenges and Public Service Commission." In Service Commission. ed. Issues in Public Service Commission. Kathmandu: Public Service Commission, 2007.

Gaige, Fred and John Scholz. "The 1991 Parliamentary Elections in Nepal: Political Freedom and Stability." Asian Survey 31-11. November 1991, pp. 1040-1060.

Ganguly, Sumit and Brain Shoup. "Nepal: Between Dictatorship and Anarchy." Journal of Democracy 16-4. October 2005, pp. 129-143.

Ghimere, Ram K. "2046 salko jana andaloka ghatanhauharuko binran: ek addhyan" [A Study on the Mass Movement 1990]. Contributions to Nepalese Studies 19-2. July 1992, pp. 283-307.

Gupta, Anirudha. "Nepalese Congress and Post-Panchayat Politics." Economics and Political Weekly 29-43. 22 October 1994, pp. 2798-2801. 
Hachhethu, Krishna. "Mass Movement 1990." Contributions to Nepalese Studies 17-2. October 1990, pp. 432-462.

. "Nepal in 1996: Experimenting with a Coalition Government." Asian Survey 37-2. February 1997, pp. 149-154.

. "The Nepal State and Maoist Insurgency, 1996-2001.” In Michael Hutt. ed. Himalayan People's War: Nepal's Maoist Rebellion. Indiana: Indiana University Press, 2004.

Hall, Andrew. "Nepal: An Incomplete Peace." Asian Affairs 42-3. October 2011, pp. 403-418.

Haque, M. Shamsul. "Incongruity between Bureaucracy and Society in Developing Nations: A Critique." Peace \& Change 22-4. October 1997, pp. 432-462.

Hutt, Michael. "Drafting the Nepal Constitution, 1990." Asian Survey 31-11. November 1991, pp. 1020-1039.

. "Monarchy, Maoism and Democracy in Nepal." Conflict, Security \& Development 1-2. 2001, pp. 93-101.

Jamil, Ishtiaq and Rameshwor Dangal. "The State of Bureaucratic Representativeness and Administrative Culture in Nepal." Contemporary South Asia 17-2. May 2009, pp. 193-211.

Khadka, Narayan. "Crisis in Nepal's Partyless Panchayat System: The Case for More Democracy." Pacific Affairs 59-3. Autumn 1986, pp. 429-454. . "Democracy and Development in Nepal: Prospects and Challenges." Pacific Affairs 66-1. Spring 1993, pp. 44-71.

. "Factionalism in the Communist Movement in Nepal." Pacific Affairs 68-1. Spring 1995, pp. 55-76.

Khanal, Y. K. "Nepal in 1997: Political Stability Eludes." Asian Survey 38-2. February 1998, pp. 148-154.

Kumar, Dhurba. "Proximate Cause of Conflict in Nepal." Contribution to Nepalese Studies 32-1. January 2005, pp. 51-92.

Lawoti, Mahendra. "Exclusionary Democratization in Nepal 1990-2002." Democratization 15-2. March 2008, pp. 363-385.

. "Informal Institution and Exclusion in Democratic Nepal." Himalaya 28-1 \& 2. 2008, pp. 17-32.

Lawoti, Mahendra and Susan Hangen. eds. Nationalism and Ethnic Conflict in Nepal: Identities and Mobilization after 1990. Oxon: Routledge, 2013.

Levitsky, Steven and Luncan A. Way. "The Rise of Competitive Authoritarianism." Journal of Democracy 13-2. April 2002, pp. 51-65. 
.ed. Domestic Conflict and Crisis of Governability in Nepal. Kathmandu: Tribhuvan University, 2000.

Meyer, Thomas and Suresh C. Chalise. "Legislative Elites and the Nepalese Parliament: A Study of Their Class Characteristics." Contributions to Nepalese Studies 26-1. January 1999, pp. 27-64.

Murthy, Padmaka. "Understanding Nepal Maoist's Demand: Revisiting Events of 1990." Strategic Analysis 27-1. January-March 2003, pp. 41-55.

"Nepali Congress Bidhan 2017, 2051, 2054, 2057, 2064, 2066 Amendment." Nepali Congress. Available at <http://www.nepalesecongress.org/files/ listingfiles/Nepali\%20Congress\%20Bidhan\%202017\%20_2051,\%202 054,\%202057,\%202062,\%202064,\%202066\%20Amendment_.pdf > (Accessed on 1 December 2012).

Parajulee, Ramjee. "An Experiment with a Hybrid Regime in Nepal (19902006)." Journal of Asian and African Studies 45-1. February 2010, pp. 87-112.

. The Democratic Transition in Nepal. Boston: Rowman \& Littlefield, 2000.

Pattanaika, Smruti S. "Maoist Insurgency in Nepal: Examining Socioeconomic Grievances and Political Implications." Strategic Analysis 26-1. January-March 2002, pp. 118-130.

Regmi, Girish C. "Nepal in 1992: Exercising Parliamentary Politics." Asian Survey 33-2. February 1993, pp. 145-149.

Riaz, Ali and Subho Basu. "The State-Society Relationship and Political Conflict in Nepal (1768-2005)." Journal of Asian and African Studies 42-2. April 2007, pp. 123-142.

Shakya, Rabindra. "Public Service Commission in the Interim Constitution, 2007 and Its Future Agenda." In Public Service Commission (PSC). ed. Issues in Public Service Commission. Kathmandu: PSC, 2007.

Shastri, Sandeep and Suhas Palshikar. "Democratizing the Meaning of Democracy: Voices from South Asia." Paper presented at the conference A Global Barometer Surveys Conference: How People View and Value Democracy. Taipei Institute of Political Science, Academia Sinica. Taipei. 15-16 October 2010.

Subedi, Surya P. "The Journey from an Oligarchy to a Parliamentary Democracy: A Case Study of the Parliament of Nepal." Journal of Legislative Studies 4-4. 1998, pp. 163-182.

Suri, K. C. Political Parties in South Asia: The Challenge of Change. Stockholm: IDEA, 2007. 
Thapa, Bhekh B. "Nepal in 1991: A Consolidation of Democratic Pluralism." Asian Survey 32-2. February 1992, pp. 175-183.

Thapa, Ganga B. and Jan Sharma. "From Insurgency to Democracy: The Challenges of Peace and Democracy-Building in Nepal." International Political Science Review 3-2. March 2009, pp. 205-219.

Timalsina, Yoshoda. "Politics in Civil Service." Nepal National Weekly. June 2013. Available at <http://www.ekantipur.com/nepal/article/?id=2607> (Accessed on 1 December 2012).

Tiwari, Madhu N. "Governance Reform in Political Transition: The Case of Nepal's Civil Service." Nepalese Journal of Public Policy and Governance 24-1. July 2009, pp. 1-27.

Upreti, Bhuwan Chandra. Maoist in Nepal: From Insurgency to Political Mainstream. New Delhi: Kalpaz Publication, 2008.

Whelpton, John. A History of Nepal. Cambridge: Cambridge University Press, 2005.

"World News Briefs; After Political Reversal, Premier of Nepal Resigns." New York Times. 5 October 1997. Available at <http://www.nytimes.com /1997/10/05/world/world-news-briefs-after-political-reversal-premierof-nepal-resigns.html> (Accessed on 1 December 2012).

Zakaria, Fareed. "The Rise of Illiberal Democracy." Foreign Affairs 76-6. November-December 1997, pp. 22-43. 